\section{Effect of the Time of Day at which Honeybee Colonies are First Allowed Flight in a New Location on their Choice of Flower Species}

A FLOWER tends to present most of its pollen at a time of day characteristic of its species. Thus dandelion (Taraxacum officinale) presents its pollen between 0900 and $1500 \mathrm{~h}$, but 63 per cent between 1000 and $1100 \mathrm{~h}$, whereas apple (Pyrus malus) presents its pollen between 0800 and $1700 \mathrm{~h}$, but 67 per cent between 1200 and $1600 \mathrm{~h}^{1}$. When dandelion and apple are flowering in the same area, individual foraging bees tend to be constant to one or other species and when dandelion flowers close for the day very few bees that visited them earlier change to visiting the apple $^{2}$. It seemed probable therefore that if colonies of bees were prevented from foraging until the afternoon of the first day they were present in an apple orchard, more bees might become conditioned to apple and fewer to dandelion than if they are allowed to forage early in the morning.

To investigate this, twelve colonies in the same apiary were confined to their hives after flight on May 10, 1967, were moved to an apple orchard in flower and were then divided at random into two equal groups $30 \mathrm{~m}$ apart. The next day hives of one group were opened at $0900 \mathrm{~h}$ and hives of the other group at $1300 \mathrm{~h}$. Each hive had a pollen trap which removed about 10 per cent of the pollen loads the bees collected. The pollen was emptied from the traps at the end of each day and the proportions of dandelion and apple pollen were estimated ${ }^{3}$. Means of $36.1 \mathrm{~g}$ and $54.0 \mathrm{~g}$ of pollen per colony were trapped on May 12 and 13 but only $0.3,0.0,1.5,2.6$ and 8.5 on the next 5 days. Hence results for May 12 and 13 only are given in Table 1, but differences between the two groups on the other days were similar.

Table 1. Mran PERCENTAges OF POLLEN UOLLECTED

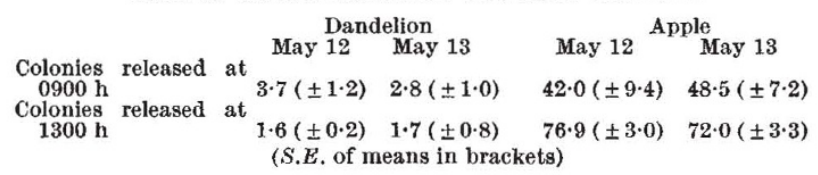

Little dandelion pollen was collected by either group and the amount did not differ significantly between the two groups, but more apple pollen was collected by the group kept in their hives until $1300 \mathrm{~h}$ (May 12, $P<0.01$; May 13, $P<0.02)$. Most other pollen collected was from: Acer pseudoplatanus, Aesculus hippocastanum, Quercus robur, Lamium album, Scilla nonscripta and Ilex aquifolium.

Confining colonies until midday increases the proportion of pollen-gatherers visiting apple. Because pollengatherers are more valuable pollinators than bees collecting nectar only, this practice probably also increases pollination. The same principle probably applies to other crops that present their pollen mostly or exclusively in the afternoon (for example, Pyrus communis, Prunus persica, Trifolium repens and Vicia faba $\left.{ }^{1,5}\right)$, but experiments are needed to establish this. Furthermore, it should be borne in mind that colonies can be damaged by confining them to their hives.

\section{J. B. Frew}

P. M. Nuttall

Rothamsted Experimental Station, Harpenden, Hertfordshire.

Received April 4, 1968.

${ }^{1}$ Percival, M. S., New Phytol., 54, 353 (1955).

${ }^{2}$ Free, J. B., J. Appl. Ecol., 5, 169 (1968).

3 Free, J. B., J. Agric. Sci., 53, 1 (1959).

4 Free, J. B., J. Hort. Sci., 41, 91 (1966).

6 Percival, M. S., New Phytol., 49, 40 (1950).

\section{Inhibition of Phage Development in Bacillus cereus Strain $T$ by Pre-spore Extracts of Bacilli}

THE susceptibility of infection of a bacillus by a bacteriophage varies with the physiological state of an organism. Goldberg and Gollakota ${ }^{1}$ observed that a phage for Bacillus cereus strain $T$ infected the organism in the vegetative stage and lysed the bacterium with the release of new phage particles. But when the phage was mixed with the pre-spores of the bacteria, the phage particles were able to adsorb to the micro-organisms but did not cause lysis of the culture. The bacilli progressed towards sporulation and produced spores as in an uninfected culture, but after germination the cells lysed. It was also shown that in these conditions the phage genome was incorporated into the spore. Investigations were carried out in order to understand the inhibition of phage multiplication during the pre-spore stage in sporulating bacilli. We report here evidence for the presence of a factor in pre-spore extracts of sporulating organisms able to suppress phage multiplication in a permissive system.

A large plaque forming phage which was used in these experiments was isolated from a phage lysate from Goldberg's original stocks. The general methodology of handling phage was according to Adams².

Bacillus cereus strain $T$, used throughout these investigations, was grown in a "G" medium from a spore inoculum by the active culture technique described by Halvorson ${ }^{3}$. This technique enabled us to obtain maximum synchrony in the culture with respect to the physiological state during the successive steps involved in sporulation. The progress of morphological differentiation was followed by phase contrast microscopy.

A 1 l. culture of $B$. cereus cells was grown to the required physiological stage by inoculating the medium with a 10 per cent $(\mathrm{v} / \mathrm{v})$ inoculum of a culture of actively growing vegetative cells. The organisms were collected and suspended in $20 \mathrm{ml}$. of $0.01 \mathrm{M}$ potassium phosphate buffer, $p \mathrm{H}$ 6.8. The cells were broken by sonication with a Branson sonifier, care being taken not to allow the temperature to rise above $10^{\circ}-15^{\circ} \mathrm{C}$ during the process. The extract was acidified to $p \mathrm{H} 5 \cdot 5$ with $1 \mathrm{~N}$ hydrochloric acid and the precipitate was removed by centrifugation. The precipitate was taken in $0.01 \mathrm{M}$ potassium phosphate buffer, $p \mathbf{H} 6 \cdot 8$, and dialysed overnight against the same buffer, $p \mathbf{H} 6 \cdot 8$, at $4^{\circ} \mathrm{C}$. Several such dialysed extracts were prepared from different stages of sporulation of Bacillus cereus strain $T$, as well as from the pre-spores of a few other spore formers. These extracts were tested for their inhibitory activity on phage multiplication in a system containing phage infected vegetative cells of $B$. cereus strain $T$.

Table 1. EFFECT OF ADDITION OF EXTRACTS FROM CELLS OF DIFPRRENT PHYSIOLOGICAL AGE ON THE PHAGT MULTIPLICATION IN $B$ cereus STRAIN $T$ Age of cells from which the

\begin{tabular}{ccc} 
extracts were prepared & PFU $/ \mathrm{ml}$. & $\%$ of inhibition* \\
$4 \mathrm{~h}$ & $2.4 \times 10^{9}$ & 33 \\
$6 \mathrm{~h}$ & $2 \cdot 3 \times 10^{9}$ & 39 \\
$8 \mathrm{~h}$ & $7.5 \times 10^{8}$ & 94 \\
$10 \mathrm{~h}$ & $2 \cdot 0 \times 10^{9}$ & $\mathbf{4 4}$ \\
$12 \mathrm{~h}$ & $2 \cdot 2 \times 10^{9}$ & 39 \\
\hline
\end{tabular}

Vegetative cells of $B$. cereus strain $T\left(5 \times 10^{7} \mathrm{ml}\right.$.) were suspended in nutrient broth. The bacteriophage at a multiplicity of 4 was mixed with the cells and the culture was allowed to stand for 5 min for adsorption of the phage to the cells. Then extracts (about $150 \mathrm{mg}$ solids $/ \mathrm{ml}$.) were added to the culture and the system was incubated for 60-70 min until lysis occurred in the control culture. The number of phage particles was determined by the usual agar overlay technique.

$$
\frac{\text { *PFU control-PFU experiment }}{\text { PFU control }} \times 100
$$

The results in Table 1 show that the maximum inhibitory activity was exhibited by extracts prepared from cells at a physiological age of $8 \mathrm{~h}$ which corresponded to the pre-spore stage of the organism. Furthermore, prespore extracts of three strains of $B$. subtilis as well as one 